\title{
Self-reported mathematical problem-solving skills of future mathematics teachers
}

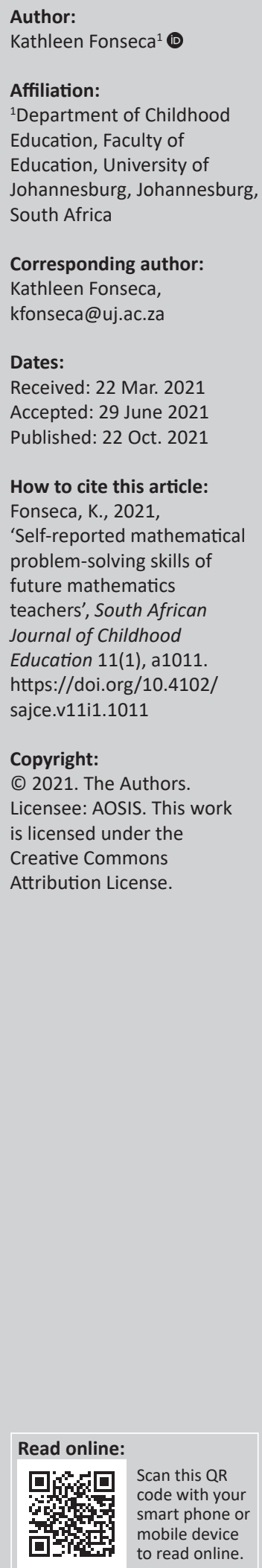

Background: During their university studies, student teachers are equipped for the teaching profession in various domains of knowledge and practice. In addition to learning pedagogic skills for practice purposes, they also expand their knowledge of the subjects that they will teach. In mathematics teacher education, one important principle is that the content of the subject must, somehow, be fused with the pedagogy in what has become known as mathematical knowledge for teaching (MKT). Although several studies have been conducted about students' performance of MKT, there is little research in South Africa about how students routinely experience the coursework itself. In this study, I argue that mathematics knowledge and skills should ideally precede the teaching of pedagogy, for reasons of communicating the concepts clearly and for building a foundation of mathematical thinking prior to practising teaching skills.

Aim: To find out what the student teachers' self-reported experience of one component of a mathematics content course are, namely their engagement with problem-solving tasks.

Methods: A qualitative case study of student teachers' learning, with the primary source of data, the student teachers' reflective journal entries. Data were analysed through coding, categorising and thematised mindful of the MPSKT framework.

Results: The findings indicated that, whilst the students' understanding of the processes of problem-solving was deepened during the course, matters of pedagogy arose spontaneously.

Keywords: initial teacher education; mathematics content courses; mathematical problemsolving; student teachers; mathematical knowledge for teaching.

\section{Introduction}

Mathematics content courses have increasingly come under the spotlight in initial teacher education (ITE) (O'Connor \&Thomas 2019; Qian \& Youngs 2016; Superfine, Li \& Martinez 2013), because of the importance of adequate mathematics content knowledge. (National Mathematics Advisory Panel 2008; Wu 2017). From a South African ITE perspective, adequate mathematics content knowledge is vital to break the cycle of mediocre primary school mathematics teaching and learning (Taylor 2019, 2021). Mathematics content courses need to address varied content strands, invariably coupled with associated pedagogies, and also with mathematical thinking skills. Amidst the various strands of mathematics, problem-solving competence is underdeveloped in most of the students that I teach. In the future, those students will have to teach young children and help them to lay the foundations of their mathematical knowledge and skills development. According to Clements and Sarama (2014), De Soete (2015), Jansen van Vuuren, Herzog and Fritz (2018), early mathematics competence is predictive of the performance throughout children's school career. In focusing on problem-solving skills, I invoke Chapman's definition of a mathematical problem as a mathematical task for which the solver typically does not have an obvious solution (Chapman 2015). Whilst there are many examples of the successful adaptation of ITE mathematics courses to address the teaching of mathematical problem-solving skills in different parts of the world, there is a dearth of research about how student teachers experience such teaching.

South African ITE for the maths content courses as well as the pedagogical components of the courses have consistently proven to have limited effect on the knowledge of future teachers of the primary school (Qian \& Youngs 2016). In South Africa, this realisation across all sectors of the education community was the main reason for the establishment of the Primary Teacher Education programme of the Department of Higher Education and Training (DHET) (PrimTEd 2019). One of the aims of 
this programme was to, eventually, establish national Mathematical Knowledge and Practice (MKP) standards for teacher education (Kortjass et al. 2021). These standards require that student teachers will not only be able to 'solve lower and higher cognitive demand tasks related to primary mathematics', but that they will also be able to 'represent, explain and justify all choices within the problem-solving process, with awareness of alternative problem-solving routes' (p. 1). The implication of this guiding principle is that, for student teachers to become competent problem-solvers, and to be able to know how to teach mathematical problem-solving, they need to engage optimally in mathematical problem-solving tasks in their university education. However, prior to the advent of PrimTEd, the ITE Research project findings (Bowie 2014; Taylor 2014) expressed doubts about whether ITE mathematics content courses adequately prepared student teachers to teach problem modelling and abstract reasoning. Given the limited knowledge on mathematical problem-solving courses implemented in ITE and considering the requirements of the standards adopted by PrimTEd, I decided to explore student teachers' self-reported experiences of such a course and then analyse their self-reported learning gains. I was mindful of what Hart and Swars (2009) have to say about listening attentively to students' voices and that their views and lived experiences should be part of the conversation around the design of mathematics courses in teacher preparation programmes.

As the course in this study was designed with the aim of developing student teachers' mathematical understanding through problem-solving, I wanted to find out what their experiences may reveal. I, therefore, asked the following research question: What are student teachers' self-reported learning experiences in problem-solving tasks?

\section{Problem-solving skills and knowledge for future teachers}

Chapman (2015) suggests that mathematics problem-solving proficiency is the direct relationship between general characteristics of successful problem-solving (Mayer \& Wittrock 2006; Schoenfeld 1985) and strands of mathematical proficiency (eds. Kilpatrick, Swafford \& Findell 2001). Chapman (2015) proposes that such a relationship includes the following components:

[C]onceptual understanding of mathematical concepts, operations and relations; understanding of general heuristics and specific strategies and when and how to use them, capacity for logical thought and understanding of reflection for awareness, monitoring, controlling and overseeing one's own cognitive processing during problem-solving; holding beliefs about mathematics, problemsolving and one's problem-solving competence that support motivation and confidence. (p. 22)

Added to these components, student teachers must also develop problem-solving proficiency. Such proficiency includes not only understanding a problem, but also knowing how to pose a problem, how to teach skills for identifying a problem, and what the role of beliefs about maths come into play when a learner tries to interpret a problem (Chapman 2015). The amalgam of components for becoming a competent problem-solver as well as an effective teacher of problemsolving is multi-faceted. In this regard, Chapman's (2015), mathematical problem-solving knowledge for teaching (MPSKT)-framework is a useful tool, as it addresses the question of what future teachers need to know to teach mathematical problem-solving.

Along with other mathematics teacher educators (MTEs) at our university, I have found that it is not feasible to engage student teachers in all seven categories of mathematical problem-solving knowledge in a single course. I would argue, although, that, even one course can establish the basis for the development of other knowledge categories in subsequent mathematics courses. In the course which I presented and which I studied as a research practitioner (Cochran-Smith \& Lytle 2009), I focused on several categories of knowledge:

\section{Mathematical problem-solving and the nature of mathematical problems}

In mathematics teacher preparation programmes, studies have shown that MTE's explored various approaches to develop a deep understanding of the knowledge domains needed for teaching mathematical problem-solving. These studies included approaches that focused specifically on the development of the strands of mathematical problem-solving proficiency (MPSP) (Guberman \& Leikin 2013; Lam et al. 2013; Masingila, Olanoff \& Kimani 2017). Others focused on the practice of student teachers' knowledge of mathematical problem-solving (Hart, Oesterle \& Swars 2013; Rapke, Husband \& Bourrie 2020; Swars et al. 2018). Research on mathematical content courses that aimed at developing student teachers' knowledge of MPS, shows that there was an increase in competence (Guberman \& Leikin 2013). There were significant changes in the students' solution strategies, which included invoking more advanced mathematics concepts and different representations. The student teachers adapted to MPS process and they started to make correlations between mathematical problems, concepts and properties (Guberman \& Leiken 2013).

Two studies, which were conducted in Singapore, showed notable findings. Data comprised student teachers' solutions to a practical MP on worksheets (Lam et al. 2013) and student teachers' reflective journals (Kaur 2017). The findings suggested that student teachers gained knowledge about MPS and its processes, as proposed by the classic four-stage model of Pólya (1945). In Lam et al.'s (2013) study, the aim was to investigate how the use of MPS practice worksheets enhanced student teachers' use of heuristics, with the findings showing that students were able to apply various heuristics, even though some were not always able to arrive at the correct solution. They were also able to expand on components of the problem once they had found the solution. In Kaur's (2017) investigation, the student teachers' reflective 
journals indicated that their knowledge gains were multiple. They gained knowledge of what a mathematical problem is and experienced the processes involved in problem-solving, such as devising a plan, using heuristics and reflecting on their problem-solving approaches. The participants also noted that through problem-solving, their creativity and curiosity were developed.

\section{Problem-solving instruction/pedagogy}

Studies about student teachers' knowledge of MPS instruction showed conflicting perspectives from both students and teacher educators. Rapke et al. (2020) found that the mathematics course was aimed at developing student teachers' knowledge of MPS instruction through a 'testdesign activity'. The activity required students to develop tests, with solutions, in groups, to exchange solution strategies and then to correct the solutions of the other students. The focus was on anticipating solution strategies and on giving feedback or asking questions to scaffold learning. Students were required to write reflective comments about their experiences of the test design task. In their comments, they noted that they should be using learners' ideas, even if it proves to be challenging. Moreover, student teachers learned that the teaching of mathematics is about connecting learners' solution strategies and expanding their reasoning by teacher feedback and discussion about solution strategies. Student teachers in Swars et al.'s (2018) inquiry noted that by focusing on children's thinking and solution strategies at the outset of a task, they were able to learn mathematics through the strategic, step-by-step process of searching strategically for a solution. The students also commented that they found the activity of thinking about how their learners might engage with tasks very useful, because it was directly applicable to how mathematics should be taught cumulatively in early grade classrooms.

Despite the usefulness of the approach described by Swars et al. (2018), there have been diverse findings in studies about the topic. For example, in Hart et al.'s (2013) cross-sectional case study, student teachers and teacher educators reported conflicting views on the usefulness of MPS courses. The student teachers said that there was a mismatch between the mathematics taught in the mathematical knowledge for teaching (MKT) course and the curriculum they have to teach in early grade classes. They found the content extremely difficult - resulting in anxiety. Their experience was worsened by some of the lecturers' 'non-supportive pedagogy' and negative disposition (Hart et al. 2013). The teacher educators' views corroborated the student teachers' negative and anxious dispositions not only regarding problem solving, but also with regard to the difficult level of the mathematics content in general. The teacher educators referred to the mismatch between the level of mathematics and the students' skill. Furthermore, only half of the teacher educators said that they enjoyed the student-centred problem-solving approach; whereas the rest noted that a student-centred instructional approach was inhibited by large class sizes, time constraints, and a lack of experience with the pedagogy. In addition, findings from Masingila et al. (2017), indicated that modelling mathematical problem-solving instruction to student teachers is not an easy task. It required that firstly, the teacher educators themselves have comprehensive mathematical understanding, before they can support the students to develop a deep and connected understanding of mathematics. In addition, they had challenges in selecting and teaching appropriate mathematical tasks, using questions to scaffold student teachers' learning without lowering the cognitive demand of the task, and engaging them in mathematical processes such as conjecturing, reasoning and proving.

\section{The inquiry}

The present study was conducted amongst a conveniently and purposefully selected cohort of $(n=62)$ student teachers with diverse levels of mathematics proficiency. The students were enrolled in a 12-week semester course in the second year of their degree programme. The course and the students were, thus, selected for the purpose of getting a glimpse of what happens in this type of naturalistic setting of a teacher education programme (Denzin \& Lincoln 2018; Merriam 2009; Onwuegbuzi \& Collins 2007).

The mathematics content course was taught in a combination of teaching approaches, including direct teaching and the Japanese structured problem-solving teaching approach (Shimizu 2003). The 12 weeks were structured to use the class of 1 week, teaching 'about' problem-solving, followed by a direct instruction (Mong \& Mong 2010; Rowe, Stephanou \& Hoad 2007) (basic skills) lecture in the following week. As the course instructor, I asked the students to complete a variety of tasks to build their basic mathematics knowledge along with the skills of problem solving (Schoenfeld 1985). The student teachers were also challenged to do all calculations without a calculator to emphasise the importance of mental computation and computational fluency. Computational fluency is one of the key components of number sense (Greeno 1991; NCTM 2000). The NCTM's (2000) Principles and Standards for School Mathematics characterises number sense in the following ways:

(1) Understand a number of ways of representing numbers, relationships amongst numbers, and number systems; (2) Understand meanings of operations and how they are related to one another; (3) Compute fluently and make reasonable estimates. (p. 32)

In addition, mental math strategies and fluently applying operations need to be developed through conceptual understanding and not by rote memorisation (NCTM 1995). Dehaene's research about 'number sense' (Dehaene 1997, 2011) affirms what behavioural researchers have shown in his neuroscience-based research, that is, understanding of number requires competence in computation.

During the mathematical problem-solving lectures, I started by addressing the student teachers' questions emanating from the previous week's tasks, and then presented a 
'problem of the week'. Students were given the option to solve the problems either in groups or individually. Most of them opted to work in groups. Thereafter, each group shared their solutions with the rest of the class, followed by the lecturer's summary. The approach served a two-fold aim developing the student teachers' mathematical understanding through problem-solving and modelling the different ways in which mathematics could be taught. Tasks and extensions were dealt with in the direct instruction lectures. In these sessions, I was able to assist student teachers to become familiar with Pólya's four-stage problem-solving framework (Pólya 1945), as with Schoenfeld's MPS framework (Schoenfeld 1985, 1992). I was also able to address student teachers' specialised content knowledge. As part of the coursework, the students were required to study the chapter, Strands of mathematical proficiency, from the book Adding it up (eds. Kilpatrick et al. 2001). The mathematics topics that featured in this chapter included sub-topics of the rational number system, such as, whole number operations and properties, fractions, decimal numbers, percentages, ratio and rate, and number theory.

\section{Research design and methods}

As a research practitioner (Cochran-Smith \& Lytle 2009), I approached the inquiry as a case study of student learning. I relied on the basic tenets of case study research. One of these is that, the research would focus on data coming from a 'bounded system' (Stake 2005; Yin 2013), which was the mathematics content course. I wanted to find out how, during the 12-week period, the students were capable of completing the problem-solving tasks effectively. For the data, I would rely on their self-reported learning gains and experience. With that, and within the boundary of the case, was the fusion with how this part of the school curriculum, which they would ultimately have to teach, could be pedagogically envisioned. As in most case study researches, the inquiry was motivated by an interest in the process more than the outcomes, in the context rather than in a specific variable, and in the discovery rather than in confirmation (Merriam 1998; Smith 1978).

The primary source of data were student teachers' reflective journal entries, which, I reasoned, would provide insight into their understanding of what constitutes MPS. At the same time, they would express their understanding of the importance of accuracy, and of the heuristics and representations used when solving problems. The journal entries provided insights about individuals which whole classroom discussions could not. Journal writing provided an 'alternative "voice" to those not good at expressing themselves' (Moon 1999a:194). Journal writing is also credited for being 'valuable to student teachers for developing metacognitive abilities and for promoting their self-orientation and responsibility for the process of their personal and collaborative learning' (Bashan \& Holsblat 2017). The journal entries showed me as teacher educator what the students' thoughts, struggles and possible transformation as part of their learning (Dunlap 2006) could arguably be.
The journal writing in this study required that student teachers think back on each of the six problem-solving class periods as soon as possible after the experience and before the memory of it would fade. This meant that the students had to reflect on their learning after every MPS lectures. According to Boud (2001), reflection after an event has taken place, is just not a process of thinking, but it includes three elements that he refers to as follows: return to experience, attending to feelings and re-evaluation of experience. 'Return to experience' refers to mentally revisiting and giving a clear and rich account of what happened in the form of written composition. 'Attending to feelings' is important because the level of reflection and learning can either be inhibited or enhanced, as negative feelings experienced may 'block' further learning, and positive feelings experienced by the writer could enhance further learning. The process of 're-evaluation of experience' includes relating new information to existing knowledge and making connections between new and prior ideas (Boud 2001). Students' journal compositions were submitted as an assessment and were structured to capture their responses to the following three prompting questions:

- What is the most significant change in your mathematical understanding since taking this course?

- How did working on the problems of the week help you to understand mathematics at a deeper level?

- Do you think the whole class discussion is helpful in gaining a deeper understanding of mathematical concepts? Why?

In this article, I used responses to the first two questions to generate data, as they focused specifically on student teachers' perceptions of the problem-solving approach in the course and their overall learning gains.

\section{Data analysis}

The responses of each student were captured in separate documents in a table format. These were read carefully to acquire an overarching view before being coded, using Saldána's $(2009,2013)$ process of 'in-vivo' coding. Much like the open coding and axial coding suggested by Strauss and Corbin (1998), units of meaning were labelled with a descriptive 'code'. (Henning, Van Rensburg \& Smit 2004). Phrases or sentences from the students' texts were identified to 'prioritize and honour the participant's voice' (Saldána 2009:74). In this process, the frequencies of a phrase in the data indicated repeated ideas and gave 'an idea of the prevalence of thematic responses across responses' (Namey et al. 2007:141). After all the in-vivo (open) coding was complete, all data items were traced to find codes that could be collapsed into categories, which were no longer descriptive, but conceptual abstractions. In the next step, the categories were thematised by showing how the categories intersected. Similar sub-themes were clustered into one overarching theme, and the qualitative data were then transformed into numerical frequencies, for example, percentages (Creswell 2009). The analysis was not conducted 
in grounded theory mode, but data were coded, categorised and thematised, by being mindful of the framework that served as a lens for the study (Charmaz 2017).

\section{Findings}

From the analysis of the content of the journals, three themes were identified. These themes capture students' self-reported learning gains about the advantages of understanding mathematical concepts and of mathematical processes, such as problem-solving.

\section{Mathematical proficiency and the intersection of conceptual and procedural knowledge}

More than a quarter of the students $(n=17)$ reported an increase in their understanding of three of the strands of mathematical proficiency, namely conceptual understanding, procedural fluency, and a personal disposition during the course. These include both learning about the importance of mathematical proficiency, and the development of their own proficiency. The responses also indicated a deeper understanding of certain concepts, the interconnectedness of mathematical concepts, and the use of proper mathematics terminology. The following excerpts underscore this:

'The most significant thing that happened to my mathematical understanding since taking this course was understanding the levels of mathematical proficiency in order to adapt and to reason and understand how to get to an answer, and what levels of mathematical proficiency I should focus in when solving certain mathematical concepts.' (Student teacher [ST]38)

'The most significant change that has ever happened to my mathematical understanding since taking this course is the radical interconnectedness of many mathematical concepts, I now understand that every complex mathematical problem is comprised of simple, individual concepts, which form a holistic challenge. This has informed both my learning (as a student) and my teaching practice (as a future teacher), in the sense that I believe tackling all small concepts is paramount to interpreting the nature of complex concepts.' (ST14)

'The most significant change that has happened to my mathematical understanding is that now I can link various mathematical concepts and not use or see them in isolation; for example, (when working with ratios, I need sound understanding and use of certain operations such as divisions and multiplication). I can now try to connect a number of concepts under one mathematical problem.' (ST36)

The data also point to $66 \%(n=41)$ of the students becoming aware of the importance of conceptual understanding in mathematics and not just knowledge of procedures. Understanding a network of concepts, or being able to link various concepts, is synonymous with conceptual understanding (Hiebert \& Carpenter 1992). In addition to learning about the interconnected nature of mathematics, $35 \%$ of the participants $(n=22)$ reported that their understanding of mathematics had improved from what they had learned in high school. They referred to improved understanding of specific concepts, skills and of mathematical terminology (and overall discourse) as exemplified in the following excerpt:

'In this course, I learnt so many mathematical terms and their meaning like ratios, fractions exponents, surds, etc. and I am able to try to use them in an appropriate situation.' (ST43)

In a similar manner, ST20 indicated the improvement in his use of mathematical terminology and overall discourse beyond vocabulary in the following words:

'The significant change that has happened since this course is that my Mathematical language has improved, as I now understand what is meant by quotient, and ratio. I have also improved in solving ratio word problems as I never understood before how to analyse and solve one before taking this course.' (ST20)

In addition, as one of the main rules of the course was that calculators were not permitted, students were required to give attention to their competence in mental calculations. There were numerous reports about its benefits. One student responded as follows:

'Since I took this course my mathematical understanding has improved lot, it helped me a lot because now I can do different problems without using a calculator, which is something that I did not know because I was using calculator until grade 12. I can see that the calculator spoiled me because I even used it for simple calculations like $7 \times 8$ just because I was used to it.' (ST46)

Similarly, ST16, said:

'I always used a calculator at high school so my basic mathematical operations like adding, subtracting, dividing, and multiplying were not well developed. Now I am able to do maths mentally without any calculator, which is very important for an intermediate teacher because I have to pass the same skills to the learners.' (ST16)

These learning gains also seem to have affected the students' attitudes towards mathematics, which Kilpatrick et al. (eds. 2001) refer to as cultivating a productive disposition. There was a definitive positive shift in their attitudes towards mathematics. The following extracts capture this:

'I have learnt to use five strands of math's proficiency for the first time. So, it helped me to think positively towards mathematics. You develop pride and confidence in your ability to understand complicated things. This is not fake-self-esteem but is earned.' (ST15)

\section{Mathematical problem-solving: A change in perspective of mathematics knowledge and its pedagogy}

The students reported that the 'problem-of-the-week' encouraged them to use multiple solution strategies. This broadened their understanding of mathematics processes and procedures:

'I now understand that there are many ways to solve a problem because back in High school we were only given one fixed method. There are many other ways of solving a problem rather than just the methods I learnt in school.' (ST3) 
ST12 noted that she realised that mathematics is not only about getting answers but also about having appropriate strategies for solving problems:

'When I first attended this course, I thought that primary school Maths is not that difficult, and I didn't pay much attention to what I was required to do. As I engage with the course, I realize that mathematics is not only about getting the answer, but you need to have strategies of solving mathematics problems.' (ST12)

Many students highlighted the importance of understanding the problem statement before deciding on a heuristic for solving the problem. They pointed out that whilst the correct answer was important, it was vital to understand why the answer was correct. For instance, ST16 and ST2 made the following comments:

'Most of these problems usually got me out of my comfort zone. They required me to connect different concepts and design my own strategies in order to solve them. A lot of them were very tricky, so they gave me analysing skills. Now I see the importance of understanding the questions. It is very important for me to understand what is being asked in a question before I could go further in attempting to solve the problem.' (ST16)

'I have learnt how to use different methods into getting to an answer BUT I have also realized that not every method is applicable to every solution. That one needs to understand what the question actually entails.' (ST2)

ST38 and ST31 commented that by solving the weekly problems, it made them aware that understanding and reasoning, and being strategically competent, are important in mathematics:

'It helps me understand that mathematics is not only about getting the answer correct and knowing all your formulas in order to be proficient in mathematics but it's about reasoning and devising different solution on your own first and trying to solve problems on your own first.' [ST38]

'Those of us who come from township schools where maths is mostly taught by teachers who are far from being subject specialist and have little effective maths methodology, we were taught that a mathematical problem can only be solved in a certain way. Teachers usually limited us to what they knew and did not allow us to explore different ways of solving the same problem. People may know the steps to follow when solving a problem but when they are faced with a problem that falls within their current focus topic, they might struggle to solve it just because it may be posted differently from what they are used to, simply because they learnt the procedures without understanding the reasons behind each step.' (ST31)

\section{The complex nature of problem-solving and the importance of prior knowledge}

The third theme relates to the student teachers' increased awareness of the importance of prior mathematical knowledge and of knowledge resources that are needed when solving problems. Schoenfeld (1985) argues that knowledge resources are required for the solving of mathematical problems successfully. Sixty per cent $(60 \%)$ of the participations indicated that they recognise the importance of prior mathematics knowledge (i.e. the necessary domain concepts and procedures) to solve problems. Schoenfeld (1985) suggested that the knowledge of facts, algorithms and routine procedures are crucial for solving problems in mathematics. Two students' expressions support this fact.

\section{ST11 said:}

'Using different methods helps in verifying if the answer is correct as well as choosing the preferable method that can be understood better. Having knowledge in other mathematical concepts also plays a major role in helping me solving the problem would be applying the knowledge I have in fractions in converting the mixed fractions to simple fractions.'

\section{ST34 also points this out:}

'When doing mathematics everything is related with one another. To work out a current problem you will need to use your prior knowledge on concepts that you have learnt and how to use them in the present concept. Your prior knowledge and knowing how to link concepts will advantage you when dealing with unknown work.'

In addition, STs commented that mathematics and problemsolving are complex in their very nature and felt that it challenged their thinking, because it required critical thinking.

\section{ST54 and ST6, captured it as follows:}

'Mathematics can be very complex in that since that you can get many different solutions to a problem but you should be able to explain how and what methods, steps or strategies you used to get to the answers.' (ST54)

'The most significant change that happened to my mathematical understanding since taking this course is gaining deeper understanding of how to solve the problems and that problem solving is very complex not the type "problem solving" that I was exposed to in my schooling.' (ST6)

\section{Discussion and conclusion}

The overall finding from the analysis of student teachers' self-reported learning gains shows a positive shift in terms of understanding what mathematics is. They learnt that knowing mathematics content is a prerequisite for MPS. Furthermore, they understood that it is equally important to acquire the intellectual tools, such as different mathematical problem-solving approaches (Harel 2013).

Another key aspect of the participants learning is that they realised that there are various strategies or heuristics they could use to solve a problem. This was, however, only possible once they had a clear understanding of what the problem comprised. Heuristics play an important role in non-routine problems of unfamiliar topics. What is apparent from the findings is that the participants had learnt various heuristics from one another. Moreover, they have learnt that it is important to reason and to justify the appropriateness of the solution path/s they follow.

Whilst the students reported that they had gained a deeper understanding of mathematical problem-solving processes, 
it is evident that their individual learning gains were varied. One possible reason for this sometimes-vast variance is that the participants enter the courses with different learning experiences in school. Nevertheless, a common trend is that they became aware of their lack of understanding of the specific mathematical terms and the discourse context in which a specific word or phrase appears. (Schoenfeld 1985, 1992). At the same time, they became aware of how important it is for a mathematics teacher to, not only be able to follow procedures to solve problems, but also to understand the underlying interconnected concepts and terminology. They spontaneously connected pedagogy and teacher knowledge. In this sense, the STs' thinking shifted from that of a mathematics student to that of a mathematics teacher. They all seem to be more aware that, as future teachers they needed to have a deeper understanding of mathematical concepts and the linguistic representation in words and sentences, so that they can teach the needed mathematical concepts and skills to their learners.

The findings also support the view of Volmink (2020 cited in Pijoos 2020), the chairperson of Umalusi ${ }^{1}$, who argues that problem-solving skills are not developed sufficiently in schools and that school-leavers lack the confidence to deal with non-routine problems. I concur with this view, specifically for primary education. From the participants' responses, it is evident that school learners, on average, do not develop confidence to deal with non-routine problems and with the multi-faceted elements of problem-solving. The implication is that it becomes extremely difficult to address this during the students' pre-service education. Despite the considerable learning gains reported by the students, I question whether a 4-year programme, with only three to four mathematics content modules, can bring about a sustainable change in the students' knowledge and their overall disposition to and its pedagogy for the primary school. I am increasingly concerned that a period of 4 years is insufficient to overcome the 12 years of mathematics instruction in which problem-solving skills were not adequately developed. Whilst the findings of the study showed the student teachers' self-reported learning improvement, these findings also highlight the students' lack of facts, concepts and understanding of the basic lexicon of mathematical terms. This disturbing finding resonates with what Taylor (2021:9) concludes: 'Tests based on the school curriculum indicate that final-year B.Ed students are quite unprepared to teach mathematics in primary schools, revealing very significant shortcomings in ITE curricula'. He is referring to the first assessment outcomes of B.Ed Foundation Phase students' performance on a mathematics test conducted by the PrimTEd assessment work stream researchers, in which student teachers from 11 universities were tested. His distressing conclusion about ITE for mathematics teaching is that interventions often fail. I propose that in-depth inquiries about the practice of mathematics teacher education may shed some light on this thorny issue.

1.Umalusi is a South African council that sets and monitor standards for general and further education and training.
I conclude with the thought that the dual focus of direct instruction and in-class tasks, coupled with student's journal writing, may shed more light on the gargantuan problem about which Taylor (2021) writes and that is captured in the title of his article. 'The dream of Sisyphus: Mathematics education in South Africa'. In a footnote, he refers to the Greek mythology tale of how Sisyphus was punished in Hades by having to push a huge boulder up a hill, only to see it rolling down the hill again, and having to repeat the action. My expectation is that ITE for mathematics teaching in the primary school will use evidence from small case studies such as mine along with large-scale assessments to find a remedy for the boulder to remain on the hilltop.

\section{Acknowledgements}

The author acknowledges the cohort of second year student teachers who willingly participated in this study.

\section{Competing interests}

The author declares that she has no financial or personal relationships that may have inappropriately influenced her in writing this research article.

\section{Authors' contributions}

I am the sole author of this article.

\section{Ethical considerations}

Ethical clearance was obtained from the University of Johannesburg Faculty of Education Ethics Committee (Ethical Clearance nr: Sem 2 2018-024).

\section{Funding information}

A bursary for this study was awarded by the: Learning Science in and for the Primary School: Student Teachers' Knowledge and Children's NRF-DST Theory. Grant no: SARC90372.

\section{Data availability}

Data sharing is not applicable to this article as no new data were created or analysed in this study.

\section{Disclaimer}

The views and opinions expressed in this article are those of the author and do not necessarily reflect the official policy or position of any affiliated agency of the author.

\section{References}

Bashan, B. \& Holsblat, R., 2017, 'Reflective journals as a research tool: The case of student teachers' development of teamwork' Cogent Education 4(1), 1374234. https://doi.org/10.1080/2331186X.2017.1374234

Boud, D., 2001, 'Using journal writing to enhance reflective practice', New Directions for Adult and Continuing Education (90), 9-18. https://doi.org/10.1002/ace.16

Bowie, L., 2014, 'Initial teacher education research project', Report on mathematics courses for intermediate phase student teachers at five universities, JET Education Services, Johannesburg.

Chapman, O., 2015, 'Mathematics teachers' knowledge for teaching problem solving', LUMAT 3(1), 19-26. https://doi.org/10.31129/lumat.v3i1.1049 
Charmaz, K., 2017, 'The power of constructivist grounded theory for critical inquiry', Qualitative Inquiry 23(1), 34-35. https://doi.org/10.1177/1077800416657105

Clements, D.H. \& Sarama, J., 2014, 'The importance of the early years', in R.E. Slavin (ed.), Science, technology and mathematics (STEM), pp. 5-9, Corwin, Thousand Oaks, CA

Cochran-Smith, M. \& Lytle, S., 2009, Inquiry as stance: Practitioner research for the next generation, Teachers College Press, New York, NY.

Creswell, J.W., 2009, Research design: Qualitative, quantitative and mixed methods approaches, 2nd edn., Sage, Thousand Oaks, CA.

Dehaene, S., 1997, The number sense: How the mind creates mathematics, Oxford University Press, Oxford.

Dehaene, S., 2011, What is number? In number sense: How the mind creates mathematics, 2nd edn., pp. 214-233, Oxford University Press, New York, NY.

Denzin, N.K. \& Lincoln, Y.S., 2018, The SAGE handbook of qualitative research, 5th edn., Sage, Thousand Oaks, CA.

De Soete, A., 2015, 'Cognitive predictors of mathematical abilities and disabilities', in R.C. Kadosh \& A. Dowker (eds.), The Oxford handbook of mathematical cognition pp. 915-932, Oxford University Press, Oxford.

Dunlap, J.C., 2006, 'Using guided reflective journaling activities to capture students' changing perceptions', Techtrends: Linking Research \& Practice to Improve Learning 50, 20-26. https://doi.org/10.1007/s11528-006-7614-x

Greeno, J.G., 1991, 'Number sense as situated knowing', Journal for Research in Mathematics Education 22(3), 170-218. https://doi.org/10.5951/jresematheduc. 22.3.0170

Guberman, R. \& Leikem, R., 2013, 'Interesting and difficult mathematical problems: Changing teachers' views by employing multiple-solutions', Journal of Mathematics Teacher Education 16, 33-56. https://doi.org/10.1007/s10857-0129210-7

Harel, G., 2013, 'DNR-based curricula: The case of complex numbers', Journal of Humanistic Mathematics 3(2), 2-61. https://doi.org/10.5642/jhummath.201302.03

Hart, L.C., Oesterle, S. \& Swars, S.L., 2013, 'The juxtaposition of instructor and studen perspectives on mathematics for teachers' courses', Educational Studies in Mathematics 83(3), 429-451. https://doi.org/10.1080/14794802.2012.694281

Hart, L.C. \& Swars, S.L., 2009, 'The lived experiences of elementary prospective teachers in mathematics content coursework', Teacher Development 13(2), 159-172. https://doi.org/10.1080/13664530903043988

Henning, E., Van Rensburg, W.A. \& Smit, B., 2004, Finding your way in qualitative research, Van Scheik, Pretoria.

Hiebert, J. \& Carpenter, T.P., 1992, 'Learning and teaching with understanding', in D.A Grouws (ed.) Handbook of research on mathematics teaching and learning, pp. 65-97, Macmillan, New York, NY.

Jansen van Vuuren, E., Herzog, M. \& Fritz, A., 2018, 'Meerkat Maths - A comprehensive maths learning programme for grade- $R$ ', South African Journal of Childhood Education 8(2), a565. https://doi.org/10.4102/sajce.v8i2.565

Kaur, B., 2017, 'Impact of the course teaching and learning of mathematics on preservice grades 7 and 8 mathematics teachers in Singapore', ZDM: Mathematic Education 49, 265-278. https://doi.org/10.1007/s11858-016-0830-8

Kilpatrick, J., Swafford, J. \& Findell, B. (eds.), 2001, Adding it up: Helping children learn mathematics, National Academy Press, Washington, DC

Kortjass, M., Mphahlele, R., Van der Haar, H., Webb, L., Matthews, C. \& Henning, E., 2021, Glimpses into primary school teacher education in South Africa, in S. Gravett \& E. Henning (eds.), Routledge Taylor and Francis Group, pp. 104-114, Routledge, $\&$ E. Henning (eds.), Ro
London and New York.

Lam, T.H., Seng, Q.K., Guan, T.E., Hoong, L.Y., Choon, T.P., Him, H.F. et al., 2013 , Infusing problem solving into mathematics content course for pre-service secondary school mathematics teachers', The Mathematics Educator 15(1) 98-120.

Masingila, J.O., Olanoff, D. \& Kimani, P.M., 2017, 'Mathematical knowledge for teaching teachers: Knowledge used and developed by mathematics teacher educators in learning to teach via problem solving', Journal of Mathematics Teacher Education 21, 429-450. https://doi.org/10.1007/s10857-017-9389-8

Mayer, R.E. \& Wittrock, R.C., 2006, 'Problem solving', in P.A. Alexander \& P.H. Winne (eds.), Handbook of educational psychology, 2nd edn., pp. 287-304, Erlbaum, Mahwah, NJ.

Merriam, S.B., 1998, Qualitative research and case study applications in education Jossey-Bass, San Francisco, CA.

Merriam, S.B., 2009, Qualitative research: A guide to design and implementation, Jossey-Bass, San Francisco, CA.

Mong, M. \& Mong, K., 2010, 'Efficacy of two mathematics interventions for enhancing fluency with elementary students', Journal of Behavioural Education 19, 273-288. https://doi.org/10.1007/s10864-010-9114-5

Moon, J., 1999a, Learning journals: A handbook for academics, students and professional development, Kogan Page, London.
Namey, E., Guest, G., Thair, L. \& Johnson, L., 2007, 'Data reduction techniques for large qualitative data sets', in G. Guest \& K. MacQueen (eds.), Handbook for teambased qualitative research, Altamira Press, Lanham, MD.

National Council of Teachers' of Mathematics (NCTM), 2000, Principles and standards for school mathematics, National Council of Teachers' of Mathematics, Reston, VA.

National Mathematics Advisory Panel, 2008, Foundations for success: The final report of the national mathematics advisory panel, U.S. Department of Education, Washington, DC.

O'Connor, M. \& Thomas, J., 2019, Australian secondary mathematics teacher shortfalls: A deepening crisis, Australian Mathematical Sciences Institute, viewed
06 August 2020, from https://amsi.org.au/wp-content/uploads/2019/05/amsi06 August 2020, from
occasional-paper-2.pdf.

Onwuegbuzi, A.J. \& Collins, K.M., 2007, 'A typology of mixed methods sampling designs in social science research', Qualitative Report 12(2), 281-316.

Pijoos, I., 2020, 'Maths teachers must teach differently says Umalusi after poor matric results', Times Live [online], viewed 11 February 2021, from https://www. timeslive.co.za/news/south-africa/2020-01-03-maths-teachers-must-teachdifferently-says-umalusi-after-poor-matric-results/\#: :text=ST\%20DailyMaths\%20teachers $\% 20$ 'must $\% 20$ teach $\% 20$ differently' $\% 2 \mathrm{C} \% 20$ says,Umalusi $\% 20$ after $\% 20$ poor $\% 20$ matric $\% 2$ results\&text=The $\% 20$ Council $\% 20$ for $\% 20$ uality $\% 20$ Assurance, showing $\% 20$ any $\% 20$ signs $\% 20$ of $\% 20$ improvement.

Pólya, G., 1945[1957], How to solve it, 2nd edn., Princeton University, Princeton, NJ.

Qian, H. \& Youngs, P., 2016, 'The effect of teacher education programs on future elementary mathematics teachers' knowledge: A five country analysis using TEDS-M data', Journal of Mathematics Teacher Education 19, 371-396. https:// doi.org/10.1007/s10857-014-9297-0

Rapke, T., Husband, M. \& Bourrie, H., 2020, 'Blurring the border between teacher education and school classrooms: A practical testing activity for both contexts', in N. Radakovic \& L. Jao (eds.), Borders in mathematics pre-service teacher education, pp. 163-184, Springer Nature, Switzerland.

Rowe, K., Stephanou, A. \& Hoad, K., 2007, A project to investigate effective 'Third Wave' intervention strategies for students with learning difficulties who are in mainstream schools in Years 4, 5 and 6, Final report to the Australian Government Department of Education, Science and Training, Australian Council for Educational Research, Camberwell, Victoria.

Saldána, J., 2009, The coding manual for qualitative researchers, Sage, Thousand Oaks, CA.

Saldána, J., 2013, The coding manual for qualitative researchers, SAGE Publications, Los Angeles.

Schoenfeld, A.H., 1985, Mathematical problem solving, Academic Press, Orlando, FL.

Schoenfeld, A.H., 1992, 'Learning to think mathematically: Problem solving metacognition, and sense-making in mathematics', in D. Grouws (ed.), Handbook for research on mathematics teaching and learning, pp. 334-370, Macmillan, New York, NY.

Shimizu, Y., 2003, 'Problem solving as a vehicle for teaching mathematics', in F.K. Lester \& R.I. Charles (eds.), Teaching mathematics through problem solving: Pre-kindergarte - Grade 6, National Council of Teachers of Mathematics, pp. 197-221, Reston, VI.

Smith, L.M., 1978, '8: An evolving logic of participant observation, educational ethnography, and other case studies', Review of Research in Education 6(1) 316-377. https://doi.org/10.3102/0091732X006001316

Stake, R.E., 2005, 'Qualitative case studies', in N.K. Denzin \& Y.S. Lincoln (eds.), The Sage handbook of qualitative research, pp. 443-466, Sage, Thousand Oaks, CA.

Strauss, A. \& Corbin, J., 1998, Basics of qualitative research: Techniques and procedures for developing grounded theory, 2nd edn., Sage, Newbury Park, CA.

Superfine, A.C., Li, W. \& Martinez, M.V., 2013, 'Developing preservice teachers' mathematical knowledge for teaching: Making explicit design considerations for a content course', Mathematics Teacher Educator 2(1), 42-54. https://doi. org/10.5951/mathteaceduc.2.1.0042

Swars, S.L., Smith, S.Z., Smith, M.E., Carothers, J. \& Myers, K., 2018, 'The preparation experiences of elementary mathematics specialists: Examining influences on experiences of elementary mathematics specialists: Examining influences on
beliefs, content knowledge, and teaching practices', Journal of Mathematics Teacher Education 21(2), 123-145. https://doi.org/10.1007/s10857-016-9354-y

Taylor, N., 2014, An examination of aspects of the BEd curricula for intermediate phase teachers at five higher education institutions, JET Education Services, Johannesburg.

Taylor, N., 2019, 'Inequalities in teacher knowledge in South Africa', in N. Spaull \& J. Jansen (eds.), South African schooling: The enigma of inequality: A study of the present situation and future possibilities, pp. 263-282, Springer Nature, Cham.

Taylor, N., 2021, 'The dream of Sisyphus: Mathematics education in South Africa', South African Journal of Childhood Education 11(1), a911. https://doi. org/10.4102/sajce.v11i1.911

Wu, Z., 2017, 'Effects of using problem of the week in teaching on teacher learning and change in algebraic thinking and algebra', ZDM: Mathematics Education 49, and change in algebraic thinking and algebra', ZDM: M

Yin, R.K., 2013, Case study research design and methods, 5th edn., p. 282, Sage, Thousand Oaks, CA. 